\title{
Political Ethics Versus Political Pragmatism: Political Voting Behaviour in Semarang Local Election
}

\author{
Hermini Susiatiningsih \\ Department of Politics and Government Science \\ Universitas Diponegoro \\ Semarang, Indonesia \\ h32minis22@gmail.com
}

\begin{abstract}
In practice, there are not many attention paying to the consent of political ethic in local politics of Indonesia. The questions of how to win the local election are much more prioritized rather than to stop political immoralities. These political immoralities in the local election may refer to several political practices such as money politics, black campaign and abuse of power of bureaucracy and city political leaders (such as a city mayor). The main objective of this research is to provide an interesting insights about the tension between political ethics versus political pragmatisms, especially related to political voting behavior in 2015 Semarang local election.
\end{abstract}

Keywords-Political ethics, money politics, black campaigns, political neutrality.

\section{INTRODUCTION}

Election in democratic state is not only designed to result in elected leaders but also to guarantee that democratic processes are taken place. Democratic processes refer to several aspects such as fair political competition, respect to individual political rights, neutral bureaucracies and professionalism of election commission. In order to guarantee the processes, election supervisory watch and political social control by people are needed in the election process. This is important because political ethic is also imposed in a democratic election. Political ethic is needed to enforce to provide good and fair competition in political life.

However, in practice, there are not many attentions paying to the consent of political ethic in local politics of Indonesia. The questions of how to win the local election are much more prioritized rather than to stop political immoralities. These political immoralities in the local election may refer to several political practices such as money politics, black campaign and abuse of power of bureaucracy and city political leaders (such as a city mayor).

Candidates and political parties tend to do everything to win an election without considering the significance of ethical values and norms. As generally known, politics is then perceived as winning every competition without considering ethics or norms. As a result, the ideality of fair and good election may be difficult to reach since many stakeholders in political elections are only obsessing the political victory by doing everything either with morality or immorality.

\section{RESEARCH METHOD}

The research method of political ethics versus political pragmatism in 2015 Semarang local election occupies survey and qualitative types which are best suitable to deeply discover trends, processes or contexts behind the phenomena studied [1]. Survey method is intended to discover political behavior of voters regarding to the inquiries about ethical problems in dealing with political election and choices. Stratified random sampling was used to select respondents.

There were 1,000 respondents taken from all subdistricts of Semarang city. These 1,000 respondents were chosen from five main parts of Semarang, namely northern, western, southern, eastern and central parts of Semarang city. These 1,000 respondents were regarded as representation of total population of Semarang voters since they were all homogenous in terms of political knowledge and experience regarding to the local election. Meanwhile, qualitative method is intended to discover political behaviors of political parries and candidates related to their view and reactions to ethical concerns related to political competition in 2015 Semarang local election.

These data collection strategies areoccupied to get data related to political party and candidate behavior in reacting to the concern of political ethics versus political pragmatism in Semarang local elections. Campaigning teams are also chosen as informants to complete needed data. 


\section{RESULT FINDINGS AND DISCUSSION}

Referring to the fact that political competition in local election is not much considering political ethics or norms, it is then pivotal to study about political behavior of voters and political stakeholders in Semarang city. Obviously there is tension between the power of political ethics versus the power of political pragmatism. The power of political ethics is considering the importance of ethics and norms in winning the political competition. Whereas, political pragmatism is doing whatever to mainly win an election or political competition.

The main objective of this study is to provide an interesting insights about the tension between political ethics versus political pragmatisms, especially related to political voting behavior in 2015 Semarang local election. Political behaviors in this study refers not only to mass voters but also to candidates and also political parties. These two actors are very important elements in this study since they may be able to provide new knowledge about political behavior in practice.

True democracy is not only talking about the result or output of political competition in an election. Election is not only a way of electing a political leader. More than that, democracy in election is talking about quality of election processes. True democracy in election is concerning about how democratic processes is implemented in a political competition to struggle for power.

In a democratic election, the quality of democracy is indicated by several elements, such as respect to individual political right, direct participation in election, popular participation for every citizen required, respect to individual political choices, free and fair mechanism in election process, professional election management and also neutrality of bureaucracy from politicking process by any powerful actor or bodies.

General election either in national or local level should be managed in professional way in order to enhance the quality of election. Joseph Schumpeter mentioned that professional management of election is one important element of democracy [2]. Moreover, International IDEA, confirmed 15 standard indicators of democratic election, namely; law framework of election law; good election system; clear district or location f election management; rights to elect and be elected; professional election commission; good voters administration; vote access for candidate and political parties; democratic political campaigns; free and transparent of mass media to access elections; clear campaign budget and finance; provision of voting box; good voting calculation and tabulation; existence of political witnesses of candidate and political parties; existence of election observers, and; law enforcement of election regulations.

To ensure that election may be able to be managed democratically, Ramlan Surbakti confirmed that there are seven main indicators namely: citizen equality; rule of law and law certainty; free and fair competition; participation from all election stakeholders; independent and professional election commission; integrity in voting ballot, calculation and tabulation; and electoral justice [3].

In the local election, confirmed that local government has potential influence to enhance democratic processes and decentralization. In local level, degree of responsiveness, accountability and representativeness may be high because of decentralization [4]. Continue to confirm that local accountability, political equity, and local responsiveness, can be achieved by legal territorial of power, local own income(local representative body) to control the local government through local election processes [5].

In local election practice, there are still possibilities of election violation or electoral malpractice. Electoral malpractice is often known as general election corruption, election violation or election manipulation. Election corruption can be categorised into three kinds, namely: election law manipulation, voters manipulations, and voting administration manipulation [6].

In order to minimize election violation or corruption, the existence of election watch or supervisory is very significant to improve the quality of democracy in local election. Election watch or supervisory is a activity to watch, to check and to make sure that all processes of election can be performed well. This is also intended to enhance election management integrity and credibility as well as to guarantee that election is conducted free, fair, honest and qualified.

In regard to three main questions of this research, there are several interesting result points found. First,political voting behavior of Semarang voters is clear that they do not seriously consider or think of political ethics when they are dealing with election. Majority of them considered that ethics are not so much relevant in political competition in 2015 Semarang city. Majority of respondents (75\%) confirmed that vote buying is important to determine their political choice. They mentioned that giving money is the main motivation for them in participating in Semarang local election.

They think that it is not significant to participate in election if they do not receive money from the candidate or political parties. Interestingly they will receive all money provided by the candidate or political party and there is no obligation for them to elect the candidate or political party that five them the money. It means that the voters are very selfish or egoistic since they are willing to receive money but refuse to elect the person who provides the money. Almost $50 \%$ of total respondents confirmed that they are happy to receive the money, but they do not want to be dictated in electing the candidate [7].

This picture is then clarifying the factual political behaviors of Semarang voters that non money factors (such 
as good programs, clean candidate, good performance of candidate and others) are not significantly important in steering their political choices. The Semarang voters are economically rational, in the sense that they are orientating to the money provision, not to the candidate as well as political party performance in terms of program or policy planned if they are elected.

Second, Semarang political behavior is clearly confirmed that money politics is acceptable since the winners will be paid much money when they get elected. According to them, the candidates must invest much money in order to be elected by the voters. This information was gotten from the in-depth interview with several key informants specially voters leaders of society or social groups.

Almost all key informant interviewed confirmed that because the elected candidate will have very high salary when they become mayor or vice mayor of Semarang city, it is rational or logical if they have to provide money to the voters first. They all mentioned that providing money to the voters is a logical consequence for them who run for mayor or vice mayor position. They perceived that the money provided by the candidate will be refunded after they are formally confirmed as the mayor and vice mayor. The political party will also enjoy this election victory so that it is also logical if the political party also provides money or other facilities to the voters. The strong ties between the voters and the candidates or the political parties are the money.

This framework of thinking of the voters of Semarang city confirmed that vote buying is then perceived as normality by the society. Vote buying is then seen as a part of local election in Semarang. This confirmation is controversial to the political belief or idealism that political morality is important in process of democratizing a country. Vote buying is not accepted in fair good election both in theory and in practice. Good election should be based on the principal that political competition must be fair and based on program competition supplied to the voters. The election process should be resulted in good and qualified leaders, not rich and instant people.

Third, the institutions that managing the local elections (such as KPU and Bawaslu) are not able to stop or even minimize money politics because of acceptable behavior related to money politics by the voters. These institutions are very often less power to react to the money politics. This powerless is caused by two main reasons.

First reason is that people permission to money politics results in mass practices of money politics in the local election. There is no guilty feeling for receiving money in the local election so that money politics become common feature of political local election in Semarang. There is no strong power either from society or their leaders to stop or challenge money politics. Money politics have been seen as normal in politics.
Second reason is that the structural forces that are driven by KPU and Bawaslu are not strong enough to find and follow money politics up in the legal processes. There are many practices of money politics in front of people, but no power of KPU or Bawaslu to tackle them. The election institutions are not having capacity to enforce the regulation or law regarding to the practices of money politics. Less participation of people in watching local election processes as well as lack of becoming a witness in a legal processes make it difficult to cope with money politics. This is recognized by a key informant from the political party who were saying that KPU and Bawaslu are powerless and very much influenced by the incumbent candidates. There were discrimination in dealing with election violation by KPU and Bawaslu. These two institutions tend to be friendly to the incumbent candidate but not to the challenging candidates. Political activists from the challenging candidates confirmed that their protests were not quickly responded by the KPU and Bawaslu since these two institutions were not independent or neutral from the influence of the incumbent. The incumbent candidate played important role in influencing KPU and Bawaslu.

Fourth, ethical problems related to bureaucracy neutrality are also widely found during the local election process of Semarang city. Bureaucracy has tendency to back politically up to the incumbent candidate. The question addressed to the voters whether they believe to bureaucratic neutrality or not, majority of them $(71.5 \%)$ confirmed that they do not believe to the neutrality of bureaucracy.

The reason for not believing to the neutrality of bureaucrac is that because of one candidate is the incumbent mayor, so that it is impossible to expect bureaucratic neutrality. A key informant from bureaucracy of Semarang who refuse to be mentioned its name, confirmed that bureaucracy has been strongly steered by the incumbent prior to the competition. The incumbent candidate has been doing everything to prepare the local competition very early. The political method to early prepare is by placing the person who loyal to the incumbent candidate in strategic bureaucratic position as such as head of Dinas/Badan or heads of districts (Camat) and heads of sub districts (kelurahan). Bureaucratic people placed in those strategic position would be loyal to the incumbent candidate for the sake of power. This is often seen as politicing of bureaucracy for political goals by the incumbent.

Finally, black campaigns are also taking place massively and indicated that political ethic is neglected in this real political competition. Several issues related to black campaigns in 2015 Semarang local elections are dealing with corruption issues of the incumbent candidate, family issues of the challenging candidate as well as personality issues of the candidates.

Black campaigns in corruption issues were addressed mainly to the incumbent candidates. The incumbent candidate was committed to several corruption issues during 
his first term of becoming Semarang city mayor. These corruption related to the physical projects in Semarang, particularly related to the project of restoring flood and rob problems in the city. Family issues was many intended to the challenging candidate, especially in terms of family disharmony and dishonesty. Personal issues in black campaigns intended almost to all candidates who take a part in Semarang local election, especially related to lack experience or capacity of personal candidate in bureaucratic experience. Interview with a key informant from the campaigning team of the candidate confirmed that war of political campaigns was very strong and it is often very rude. It seemed that there were no morality filter in dealing with this black campaigns.

\section{CONCLUSION}

It can be concluded that political behavior of Semarang voters is very pragmatic dominated by money politics. Candidates and political parties also view local election should be won by any efforts regardless of political ethics or social norms. They tend to do everything to win a local election, even using money politics or black campaign. The role of ethics in political competition in Semarang is low indicated by strong money politics and black campaigns during the political competition processes.

According to the above finding and explanation, this research paper finally attempt to empirically and theoretically provide solutions to impose political ethics in the local election through three main strategies, namely promoting good leaders, strengthening voters loyalty and imposing strong regulations.

In terms of promoting good leaders, it is important to improve public awareness about the importance if quality of leaders, based on their capacity and competence for becoming city leaders, rather than based on the money supports. Good leaders will guarantee the good quality of governance of Semarang city. Whereas leaders who win because of money will not be able to be hoped for the quality of good governance in Semarang. Money politics will only result in instant leader who will not be able to focus high quality of leadership during their government term.

Strengthening voters loyalty is important to improve political ethics in local election competition. Loyal voters will be able to decrease money politics since this loyalty will guide voters to a good leader of the city, not to the instant leader or rich leader who using money as main instrument in political relations and competitions.

Imposing regulation is very pivotal to enforce political ethics and morality. Law enforcement is intended to guarantee the excellent processes of democracy may take place in local election, especially in Semarang city. KPU and Bawaslu should be strong in imposing regulation and zero compromise to election violations. Regulation is strong instrument to improve and sustain good quality of local election in Semarang especially and Indonesia generally.

\section{REFERENCES}

[1] Creswell J.W., "Research Design: Qualitative, Quantitative and Mixed Methods Approaches", Third Edition. Los Angeles: SAGE Publication, 2009.

[2] Schumpeter. Joseph, "Capitalism, Socialism, and Democracy”, New York: Harper, 1947, pp. 122.

[3] Surbakti. Ramlan, "Pemilu Yang Adil dan Berintegritas", Kompas 14/2/2014.

[4] Antlov. Hans, "Mewujudkan Demokrasi Lokal Melalui Forum Warga", Jurnal PSPK, Edisi Juni-Juli, 2002, pp. 44.

[5] Hidayat, Syarif, "Hubungan Kekuasaan Pusat-Daerah Dalam perspektif Elit penyelenggara Pemerintah Daerah", Makalah, Seminar Internasional Ketiga "Dinamika Lokal di Indonesia: Pluralitas Dalam Perspektif Lokal", Percik, Salatiga, Jawa Tengah, tanggal 9 - 12 Juli 2002, unpublished.

[6] Birch, Sarah, "Electoral Corruption.Briefing Paper", Institute for Democracy \& Conflict Resolution (IDCR), 2011

[7] Najib, Mohammad, "Urgensi Pengawasan Partisipatif oleh Media Massa dan Ormas" in Mohammad Najib (dkk), "Pengawasan Pemilu Problem \& Tantangan, Yogyakarta: Bawaslu DIY, 2014. 